\title{
Impact of Container Nursery Production Practices on Weed Growth and Herbicide Performance
}

\author{
Cody J. Stewart, S. Christopher Marble ${ }^{1}$, and Brian J. Pearson \\ Department of Environmental Horticulture, University of Florida Institute \\ of Food and Agricultural Sciences, Mid-Florida Research and Education \\ Center, 2725 South Binion Road, Apopka, FL 32703
}

\section{P. Christopher Wilson \\ Soil and Water Sciences Department, University of Florida, 2181 McCarty Hall, Gainesville, FL 32611}

Additional index words. preemergence, postemergence, soilless-substrate, fertilizer, irrigation, ornamental

Due to the lack of postemergence herbicide options, heavy reliance on hand weeding, and high crop species diversity, weed control continues to be one of the most challenging elements of producing ornamental plants in container culture. In contrast to other production systems, container-grown ornamentals are produced almost entirely in organic substrates (pine bark, peat, etc.), are overhead irrigated one or multiple times per day, and are fertilized almost exclusively with the use of controlled-release fertilizers (CRF). Multiple aspects of weed control in and around ornamental production have been addressed with prior research. Much of this work has focused on various chemical and/or nonchemical approaches to weed management and crop response to these approaches. An area that has been subject to less investigation is what impacts various production inputs have on weed control and herbicide performance. The primary objective of this article is to provide an overview of the various methods of weed control that are currently being used and to summarize the literature that has focused on the effects of container culture production practices, such as fertilization methods, irrigation schedules, and substrate composition, have on weed growth and the performance of control measures that are employed. The secondary objective is to highlight key knowledge gaps and suggest possible avenues for future research that could potentially lead to more robust weed control protocols in container nursery production.

\section{Introduction to Current Weed Control Methods}

Nursery crop producers growing containerized ornamentals face several unique challenges pertaining to weed management. First,

Received for publication 16 June 2017. Accepted
for publication 7 Sept. 2017.
${ }^{1}$ Corresponding author. E-mail: marblesc@ufl.edu. as container-grown plants are produced in a restricted rooting environment, it only takes one weed to negatively impact crop growth and marketability (Berchielli-Robertson et al., 1990; Fretz, 1972; Walker and Williams, 1989). Fretz (1972) demonstrated that one large redroot pigweed (Amaranthus retroflexus L.) or large crabgrass (Digitaria sanguinalis L.) reduced the growth of 'Convexa' Japanese holly (Ilex crenata 'Convexa') by $47 \%$ and $60 \%$, respectively. Similarly, Berchielli-Robertson et al. (1990) reported a $43 \%$ reduction in Fashion azalea (Rhododendron $\times$ 'Fashion') from one eclipta (Eclipta prostrata L.) plant. Other studies have also reported similar growth reductions from a wide variety of weed species on many different ornamental crops (Norcini and Stamps, 1994; Walker and Williams, 1989). Research has shown that many weed species are highly competitive for water (Sands and Nambiar, 1984) and nutrients (DiTomasso, 1995) in field cropping systems and this effect is increased in a container. Second, in contrast to agronomic crops in which yield is the primary concern, most nursery crops are sold and marketed based on aesthetic value, and consumers demand weed-free pots (Simpson et al., 2002). Thus, weed control thresholds can be virtually zero in a production nursery depending upon clientele and end-user preferences.

In addition to competition and marketability concerns, many weed species have been shown to be alternative hosts for crop pests (Altieri et al., 2009). Common chickweed (Stellaria media L.) has been shown to be a host for thrips (Frankliniella fusca) (Groves et al., 2002), whereas eclipta and garden spurge (Chamaesyce hirta L.) were reported as hosts for lepidoptera species (Singh et al., 1989). Weeds can also serve as hosts for numerous bacterial or fungal pathogens, including Fusarium spp. (Jenkinson and Parry, 1994), Sclerotinia sclerotiorum (Boland and Hall, 1994), and Pseudomonas solanacearum (Hayward, 1991) and serve as a breeding ground for insect vectors of other diseases (Yudin et al., 1986). Although not a major concern in container production, weeds are also hosts of several damaging nematode species (Thomas et al., 2005; Trivedi and Barker, 1986).

As profit margins decline and the input costs continually increase, researchers and nursery growers have looked for ways to decrease production costs. From a weed control perspective, this would include many different preventative and sanitation measures, as well as chemical and nonchemical methods of weed control to improve crop growth, reduce economic burden, and increase product marketability (Case et al., 2005; Fausey, 2003).

Other than a select group of graminicides, growers have very limited postemergence options in container production. Because of the limited options, weed control in container nursery production is primarily achieved with preemergence herbicides and supplemental hand weeding. In the past, a large percentage of growers could afford to hire extra labor to assist with hand weeding efforts while still completing other production tasks. This is no longer the case as labor costs continue to increase and labor availability decreases. Mathers (2003) reported that nurseries may spend as much as $\$ 9900$ per ha on the manual removal of weeds, and economic losses due to weed infestations have been estimated at $\$ 17,300$ per ha (Case et al., 2005). Similarly, Darden and Neal (1999) reported a cost of $\$ 1367$ to hand weed 10003 -L pots over a 4-month period. While many growers can no longer afford to pay for the labor they need, others cannot find it because of long-term labor shortages that are predicted to worsen in the future (Taylor et al., 2012). Recent immigration reform and similar legislation passed in many states have caused many nursery growers to lose a large portion of their labor force while also creating a great deal of uncertainty over future availability (Johnson, 2011; Martin, 2017). Effective weed management programs could become more important economically now than they have in previous years.

Commonly used container substrate components (pine bark, peat, etc.) are typically initially weed free (Altland, 2014; Norcini et al., 2006). However, in an effort to reduce costs, growers may reuse potting media or add composts to their potting mix, which are highly likely to result in significant weed infestations. In a study by Steed (2015), a $30 \times 45 \mathrm{~cm}$ tray filled $2.5 \mathrm{~cm}$ deep with reused potting media yielded 80 weeds whereas trays filled with fresh media contained no weeds after $14 \mathrm{~d}$. Weed seed is also easily transmitted into growing media via wind, water, animals, or other means. Sanitation and preventative measures are highly important for effective weed control throughout the crop production cycle. This would include using clean soil, pots and flats, scouting; monitoring incoming shipments and liners for weeds; and keeping nonproduction areas weed free (Neal et al., 2017).

In addition to hand weeding and sanitation/ preventative measures, several nonchemical 
methods of weed control have been developed and employed with varying levels of success. One method of nonchemical control that has received some attention and adoption is the use of various types of mulch (Wilen et al., 1999). Although mulch is more commonly used in landscapes and has not been widely adopted in the container nursery industry, a number of mulches have been suggested by researchers for their ability to control weeds (Abbey et al., 2001; Mathers and Ozkan, 2001). Research has demonstrated that the use of organic mulch materials in containers can provide season-long weed control. In container plant production, Cochran et al. (2009) reported that a $2.5-\mathrm{cm}$ layer of pine bark mini-nuggets reduced weed counts of eclipta (Eclipta alba L.) by $87 \%$ and spotted spurge (Chamaesyce maculata L.) by $90 \%$ compared with a nonmulched control. Pine bark mini-nuggets were also shown to provide season-long weed control of bittercress (Cardamine hirsuta L.) when applied at a depth of $7.6 \mathrm{~cm}$ without affecting the growth of oakleaf hydrangea (Hydrangea quercifolia W.) or Natchez crape myrtle (Lagerstroemia indica 'Natchez') (Richardson et al., 2008). Similarly, an earlier study by Wilen et al. (1999) found a 92\% reduction in broadleaf weed species, including creeping woodsorrel (Oxalis corniculata L.), northern willowherb (Epilobium ciliatum Raf.), and common groundsel (Senecio vulgaris L.), present in container plants that were mulched with pinebark nuggets, composted greenwaste (municipal greenwaste), pecan hulls, or copper hydroxide-coated polypropylene fabric disks compared with plants that were left bare. Rice hulls and mustard seed meal have also been evaluated as mulch in container culture and have been effective against certain weed species. Ahn and Chung (2000) demonstrated that allelopathic compounds can be extracted from multiple rice (Oryza sativa L.) cultivars. Their work showed that the rice cultivar 'SR31' inhibited germination of barnyardgrass (Echinochloa crus-galli P. Beauv. var. oryzicola Ohwi) by $59 \%$, and extracts from 'Janganbyeo' reduced barnyardgrass dry weight by $96 \%$. In other reports, rice hulls applied at depths of $2.5 \mathrm{~cm}$ provided effective control of bittercress, creeping woodsorrel, willowherb, and common groundsel for up to 16 weeks (Altland, 2014). Boydston et al. (2008a) demonstrated that when applied to the surface of container media, mustard seed meal reduced weed counts of annual bluegrass (Poa annua L.) by up to $98 \%$, common chickweed by up to $74 \%$, creeping woodsorrel by $90 \%$, and provided up to $97 \%$ control of liverwort (Marchantia polymorpha L.). In another work by Boydston et al. (2008b), dried distiller grains with solubles, a byproduct of ethanol production, provided $40 \%$ to $57 \%$ reduction in weed control of annual bluegrass and $33 \%$ to $58 \%$ reduction in common chickweed when applied to the surface of container-grown ornamentals at rates of 800 or $1600 \mathrm{~g} \cdot \mathrm{m}^{-2}$ without reducing the growth of Coreopsis auriculata 'Nana',
Rosa hybrid 'Red Sunblaze', or Phlox paniculata 'Franz Schubert'.

Another common nonchemical weed management tool is the use of various weed discs or similar devices which are solid units (not loose-fill mulch) and placed on the container media surface, typically containing a slit on one side for the ornamental (Mathers, 2003). Several manufactures have developed weed discs or "bags" out of plastic, hair, coconut fiber, or different types of synthetic fiber (Amoroso et al., 2009; Chong, 2003). Various types of discs have been successful in certain situations. Discs made of various organic or synthetic materials evaluated by Amoroso et al. (2009) provided greater control of natural weed populations compared with an oxadiazon and a trifluralin + isoxaben preemergence herbicide application while not affecting the growth of Photinia $\times$ fraseri 'Red Robin', Prunus laurocerasus 'Rotundifolia', or Thuja plicata 'Atrovirens'. This study, however, evaluated the use of these discs in comparison with a single herbicide application. Few differences were observed earlier in the season (70 d after treatment), whereas the discs began to provide significant improvement later in the season $(140 \mathrm{~d}$ after treatment). However, it would be rare for a single preemergence herbicide application to provide control for $140 \mathrm{~d}$, especially considering that the nursery environment may accelerate herbicide degradation (Judge et al., 2003).

The downside of these mulch materials, either loose fill such as rice hulls and pine bark, or weed discs, is typically cost, limited or seasonal availability, products blowing out of containers, or being lost because of pot blow-over (Chong, 2003). While all of the various nonchemical approaches to weed control can be effective in certain situations, the material and labor costs required to employ these methods is usually the primary deterrent to widespread adoption in the industry. For example, applying a $2.5-\mathrm{cm}$ layer of hardwood mulch to a \#1 (3.8 L or 1 gal) container would cost about $\$ 0.03$ if purchased at a retail price of $\$ 56$ per $\mathrm{m}^{3}$. If a standard preemergence granular herbicide was purchased for $\$ 70$ for a $23-\mathrm{kg}$ bag and applied at a rate of $224 \mathrm{~kg} \cdot \mathrm{ha}^{-1}$, the cost for that same container would be about $\$ 0.001$ per container, close to a $97 \%$ reduction in cost without accounting for herbicide loss due to pot spacing. When considering season-long control, mulch has been shown to outperform a single herbicide application (Amoroso et al., 2009); however, if omitting labor costs, around 25-30 herbicide applications could be made before equaling the cost of certain mulch materials.

Because of the high cost of hand weeding and most nonchemical methods of control, chemical control measures are typically required to reduce costs, with most these being preemergence herbicides. A comprehensive review of common nursery pre- and postemergence herbicides has been published recently (Case et al., 2005) and has remained current. One notable addition to Case et al.
(2005) was the introduction of indaziflam for nursery use in recent years. Indaziflam is classified as an alkylazine herbicide and a cellulose biosynthesis inhibitor, inhibiting crystalline cellulose deposition in the cell wall affecting wall formation, cell elongation, and division and only affects growing meristematic regions of seeds as they emerge (Brabham et al., 2014). Relatively little research has been published on indaziflam efficacy or crop tolerance in ornamental production; however, it is labeled to control over 85 broadleaf, grass, and sedge weeds from seed (OHP Inc., 2014), and suspension concentrate formulations can provide some early postemergence activity on weed species, including smooth crabgrass (Digitaria ischaemum Schreb.), annual bluegrass, and yellow woodsorrel (Oxalis stricta L.) (Brosnan et al., 2011, 2012; Marble et al., 2013). In addition, a granular formulation is now available that is labeled for overthe-top application.

Currently, most container nursery growers are making between two and six preemergence herbicide applications per year to a given area of production space using primarily granular herbicide formulations (Gilliam et al., 1990; Marble, unpublished data). The number of applications a particular crop would receive while in production will vary greatly depending upon the amount of time needed for the crop to reach a marketable size. For example, perennial, herbaceous, or ornamental grass crops may only be in production for a few months, whereas a large woody tree or shrub may require multiple years of growth to reach the desired size. Despite frequent applications throughout the year, herbicides can still lose their effectiveness before reapplication. Once applied, herbicide degradation can occur by ultraviolet irradiation (photodegradation), volatilization, chemical degradation, microbial degradation, or leaching (Vencill, 2002). Most herbicide degradation values and reports focus on various field soils (Senseman, 2007), and those values are often assumed in container nursery conditions. However, container nursery growers use soilless-substrates which are comprised almost entirely of organic matter, pine bark and peat, and are typically fertilized differently than agronomic crops. These soilless-substrates also receive up to $1.3 \mathrm{~cm}$ or more irrigation each day, which may decrease herbicide longevity (Judge et al., 2003). While many studies have focused on leaching or runoff from herbicides after application to soilless media (Derr et al., 2015; Horowitz and Elmore, 1991; Rouchaud et al., 1999; Simmons and Derr, 2007; Williams, 2009), limited data are available on the longevity of the most common nursery herbicides under nursery conditions. In a study by Judge et al. (2003), trifluralin, a commonly used nursery herbicide, had a half-life of less than $7 \mathrm{~d}$ in soilless substrate compared with 19-132 d as previously reported in various field soils (Weber, 1990).

While most growers make multiple applications per year, reports of reduced herbicide duration in nursery conditions paired with 
reports of herbicide doses needed to control the most common nursery weeds suggest that in some regions, specifically areas with mild winter temperatures, eight or more herbicide applications may be needed per year for ideal weed control (Judge, 2001). Making eight or more herbicide applications per year poses several problems. First, it is costly to apply herbicides, particularly granular-based formulations that are most prevalent in container nurseries. Regardless of active ingredients, the average cost of a granular herbicide is about $\$ 70$ per $23 \mathrm{~kg}$ bag. Given this estimation, treatment of 1 ha would cost about $\$ 690$. For a 20 ha container nursery making six applications per year, the total chemical cost would be $\$ 83,000$, not including labor costs that may require two to three person-hours per hectare, although this is highly variable depending upon application equipment. At the average hourly rate for farm laborers in Florida (\$10; United States Department of Labor, 2015), labor for application would increase cost considerably. Second, annual use limitations restrict the number of herbicide applications that can be made with any one herbicide, which typically reduces applications to two or three times per year. If nursery herbicides cannot provide a significant duration of weed control between applications, due to environmental conditions and annual use limits, how can growers effectively manage weeds? One option would be to use different active ingredients and/or modes of action for each application. However, most nursery preemergence herbicides contain oxyfluorfen or are dinitroanaline herbicide based, and very few active ingredients are available for certain ornamental crops (Case et al., 2005). In addition, proper rotation in certain crops that are notoriously sensitive to herbicides poses a challenge. Many species, such as hydrangea, are widely grown but cannot tolerate over-the-top applications of most commonly used herbicides, limiting options for growers. An alternative to rotation commonly used on these sensitive species is to use the same herbicide that has shown good results in the past multiple times per year. This method, however, is likely to lead to exceeding annual limits, which is illegal and can lead to environmental concerns. This also would not reduce costs of making eight or more applications per year.

The answer to more efficient and economical weed control is herbicide choice; however, it is also critical to understand how various herbicides interact with different production practices. A potentially promising yet somewhat underinvestigated way to increase herbicide efficacy and duration would be to determine how herbicides interact or are impacted by various production practices, including container substrate physical properties, fertilization methods, and irrigation regimes. Weed control programs could then be developed, in part, based on these variables if determined that they significantly influence weed growth and herbicide performance.

\section{Effect of Production Practices on Weed Growth and Herbicide Performance}

Nutrient management. While proper fertilization is paramount for promoting the growth of healthy and marketable crops, many studies have shown that fertilizers benefit weeds to a greater degree than crop plants, often creating a competitive advantage for many weed species (Blackshaw et al., 2003; DiTomasso, 1995). In a study examining the response of $\mathrm{N}$ fertilization rates on wheat (Triticum aestivum L.) biomass, Blackshaw et al. (2003) observed greater shoot biomass among 15 weed species and greater root biomass among eight weed species. In most cases, weeds are able to exploit high nutrient levels to a greater degree than crop plants. It might also be expected that for a woody nursery crop, which would likely have a much slower growth rate than an annual grain crop, the competitive effects of weeds could be greater.

Nutrients are supplied to container-grown plants primarily using CRF along with lime and a micronutrient package commonly supplied with the fertilizer (Bilderback et al., 2013). Fertilizers are added to nursery substrates by incorporation, topdressing, or in rare cases subdressing or dibbling. Incorporation involves adding all soil amendments and fertilizer to the substrate that will be used for the potted plants then thoroughly mixing before potting. Topdressing involves placing the fertilizer on the container media surface after potting. This may be used as the sole method of fertilization or used in addition to incorporation or dibbling for longer-term crops. Several dibbling methods have been evaluated; however, it is often performed by placing all of the fertilizer required for a particular sized container directly below the root ball of a plant liner and requires the use of extended release fertilizer coatings. Dibbling has fallen out of favor within the nursery industry, primarily due to the chance of reduced growth or plant quality that can be associated with roots being in close or direct contact to fertilizer prills.

Research has shown that plant response to various fertilizer placements is speciesspecific and thus, no broad-based recommendations can be accurately developed (Alam et al., 2009; Cobb, 1985; Conover and Poole, 1985; Hicklenton, 1990; Klock-Moore and Broschat, 1999; Yeager and Ingram, 1987). However, dibbling or layering fertilizer (placing in a single layer beneath the surface of the container substrate) has been shown to increase or have no effect on growth in Chinese hibiscus (Hibiscus rosa-sinensis L.), bamboo palms (Chamaedorea seifrizii Burret), Areca palms (Dypsis lutescens H. Wendl.), Fishtail palms (Caryota mitis Lour.), Macarthur palms (Ptychosperma macarthurii H. Wendl.), downy jasmine (Jasminum multiflorum Burm F.), plumbago (Plumbago auriculata Lam.) (Broschat and Moore, 2003), gumpo azaleas (Azalea $\times$ hybrid 'Gumpo White') (Marble et al., 2012), and several other economically important ornamental species (Altland et al.,
2004) compared with topdressing or incorporating at similar rates.

While research has been conducted, there is a general lack of pertinent information on the impact of fertilizer placement on weed growth and more specifically, herbicide performance. Research by Altland et al. (2004) examined weed response to Osmocote $18 \mathrm{~N}-2.6 \mathrm{P}-10 \mathrm{~K}$ (18-6-12) (ICL Specialty Fertilizers, Geldermalsen, The Netherlands) applications of $12 \mathrm{~g}$ per \#1 (3.0 L) container using topdress, incorporation, or dibble application methods. Results showed that for common groundsel, prostrate spurge (Chamaesyce prostrata L.), and oxalis, dibbling resulted in weed control of $85 \%$ to $97 \%$ compared with $19 \%$ to $85 \%$ control observed in topdress and $55 \%$ to $88 \%$ control observed in incorporation treatments. When fertilizer placement methods were combined with the use of herbicides, (oryzalin + oxyfluorfen or pendimethalin + oxyfluorfen), dibbling resulted in $89 \%$ to $99 \%$ control compared with $82 \%$ to $90 \%$ for topdressing and $81 \%$ to $98 \%$ for incorporation methods across all three weed species. Broschat and Moore (2003) reported similar findings; when examining the impact of fertilizer placement on crop growth, weed biomass was either similar to or less in container-grown palms when fertilizers were layered, or placed below the soil surface, compared with incorporation or topdressed placements.

Strategic nutrient placement, such as banding, has been shown to reduce growth and emergence of multiple monocot and dicot weed species by up to $50 \%$ in agronomic crops compared with broadcast type applications (Blackshaw et al., 2004; Kirkland and Beckie, 1998; Rasmussen et al., 1996). While significant benefits have been noted following strategic fertilizer placement in agronomic studies using field soils, the impact of fertilizer placement in a soilless container medium may be far greater. As nutrients are needed upon germination and container substrates are largely inert in contrast to field soils, and contain few available nutrients (Landis, 1990), many container nursery weeds with small seeds, such as prostrate spurge, creeping woodsorrel, and common groundsel, will not grow beyond the cotyledon stage if access to nutrients is limited (Altland et al., 2004; Wada, 2005). It is likely dibbling or a modified dibble, such as layering or subdressing fertilizers would greatly reduce available nutrients to shallow germinating weed seeds, and thus reduce or prevent weed growth. However, where information is lacking is on understanding the significance of fertilizer and herbicide interactions and the impact of fertilizer placement on variables, such as microbial populations, and the resulting impact of weed control. Donnelly et al. (1993) found that as nitrogen rates increased, the rate of degradation of atrazine and 2,4-D (albeit two herbicides not labeled for use in ornamentals) also increased. This work indicated that for these two herbicides, increased microbial populations due to added nutrients might result in 
increased herbicide dissipation. By contrast, Jackson et al. (2009) reported that $\mathrm{CO}_{2}$ efflux in fallow soilless-substrates decreased with increasing fertilization rates when containers were first fertilized through incorporation and then by dibbling thereafter. Other work has shown both increased (Gough and Seiler, 2004) and decreased (Thirukkumaran and Parkinson, 2000) microbial respiration rates following fertilizer additions and combinations. However, in some cases, differences were the result of changes in autotrophic respiration rates because of increased root growth after fertilization (Gough and Seiler, 2004) which would not be as applicable when considering effects of microbial populations on herbicide degradation.

Other studies that have examined the impact of fertilization methods on weed control specifically for containers include work by Wada (2005), which evaluated the impact of lime application method and nitrogen source on weed germination and growth. In these studies, creeping woodsorrel shoot fresh weight was reduced by $66 \%$ in substrates with a pH of 6.7 compared with substrates with a $\mathrm{pH}$ of 4.4. Topdressing pulverized or pelletized dolomitic limestone provided effective control of creeping woodsorrel compared with when lime was incorporated. It is well known that nitrates, specifically potassium nitrate promotes the germination of several weed species (Andersen, 1968). However, Wada (2005) investigated the impact of nitrogen source on growth of bittercress (Cardamine oligosperma Nutt.), spotted spurge, pearlwort (Sagina procumbens L.), common groundsel, northern willowherb, and creeping woodsorrel. Results showed that, in general, calcium nitrate and magnesium nitrate reduced growth and flower number of the weed species evaluated compared with ammonium sulfate and ammonium nitrate. Weeds fertilized with ammonium nitrate were generally the largest with the highest flower and seed production. In agronomic studies, redroot pigweed had reduced shoot and root growth $(75 \%$ and $86 \%$ reduction, respectively) after ammonium-N applications when compared with those that received nitrate- $\mathrm{N}$ applications (Teyker et al., 1991). Similarly, witchweed (Striga asiatica L. and Striga hermonthica Del.) incidence has been shown to be significantly reduced in maize when fertilized with ammonium sulphate- $\mathrm{N}$ or urea when compared with ammonium-nitrate (Farina et al., 1985; Mumera and Below, 1993).

Few studies are available that have examined the impact of fertilization placement on herbicide longevity in soilless container media. It is likely that subdressing or dibbling fertilizer would reduce the growth of most container nursery weed species, especially those with small seeds and limited nutrient reserves (Altland et al., 2004). Furthermore, if microbial populations on the container surface were reduced by limiting nutrient availability (via subdressing or dibbling), herbicide degradation rates may be reduced. Further research is needed to not only determine weed and crop response to various fertilizer placements but also to determine if herbicide efficacy is impacted by various placement methods. Multiple active ingredients have become registered for use in nursery production, including dimethenamid-p, flumioxazin, and indaziflam, which are currently some of the most commonly used herbicides in nursery production. There has also been an industry-wide transition toward the use of liquid or spray-applied herbicides. Little information exists on how fertilization placement impacts performance of these formulations. Moreover, a lack of investigations examining the influence of $\mathrm{N}$ formulation on the wide array of weed species prevalent in nursery crop production precludes determination of weed response trends and commercial application recommendations.

Irrigation method. Various irrigation systems have been developed and evaluated for use in nursery crops, including subirrigation, overhead systems, and drip or micro irrigation. With the exception of subirrigation, all of these methods result in the substrate surface being wetted, providing an ideal environment for weed-seed germination (Wilen et al., 1999).

In many cases, higher soil moisture levels have been shown to be associated with higher levels of weed seed germination and growth (Asgarpour et al., 2015; Wehtje et al., 1992; Werle et al., 2014; Werth et al., 2017). Subirrigation allows water to move upward through the substrate through capillary action (Schmal et al., 2011), which has been shown to reduce weed growth. Wilen et al. (1999) reported a $95 \%$ reduction in cumulative growth of creeping woodsorrel, northern willowherb, and common groundsel when containers were subirrigated and mulched compared with unmulched, surface-irrigated controls. In related studies, subirrigation has been shown to reduce the growth of moss in container-grown ornamentals and other weed species in comparison with overhead or drip irrigation systems (Dumroese et al., 2006; Goodwin et al., 2003). Similarly, different modifications of this method, such as subsurface drip irrigation, have proven effective for reducing weed growth in field crops (Camp, 1998). In studies with tomatoes (Lycopersicon esculentum Mill.), subsurface drip irrigation reduced weed density by $46 \%$ to $96 \%$ compared with furrow irrigation (Shrestha et al., 2007) and was as effective when used alone compared with using a herbicide (napropamide + pebulate) and overhead sprinkler irrigation for controlling redroot pigweed and barnyard grass (Grattan et al., 1988).

While larger crops may be microirrigated or drip-irrigated, container-grown nursery crops are predominately irrigated using overhead systems (Bilderback et al., 2013; Burger et al., 1987). When using overhead irrigation, irrigation needs are usually met using cyclic or noncyclic irrigation schedules. In noncyclic irrigation, the full volume of water allotted to a plant is applied at one time. The alternative schedule method, cyclic irrigation, spreads similar irrigation amounts into two or more subvolumes throughout the day (Bilderback et al., 2013). In many cases, cyclic irrigation can improve crop growth while using less water and reducing runoff and nitrate leaching (Burger et al., 1987; Fare et al., 1994). While cyclic irrigation can provide significant benefits in terms of crop growth and water usage, some research suggests it may increase weed growth. Results by Fain et al. (2004) showed that spotted spurge growth increased by over $250 \%$ when cyclical irrigation practices were used compared with noncyclic irrigation practices. High frequency irrigation has also been shown to reduce the effectiveness of preemergence herbicides, including oxadiazon and oryzalin, when evaluating the control of liverwort (Svenson, 1998). Although few studies are available, one possible reason for reduced herbicide effectiveness when cyclic irrigation or other high frequency irrigation is employed is due to herbicide loss via hydrolysis and/or possibly leaching. Some preemergence herbicides have shown increased degradation rates in saturated soils compared with drier soils (Taylor-Lovell et al., 2002); however, few studies have focused on herbicide performance under high moisture levels within soilless organic substrates. More research has been conducted on leaching of herbicides in nursery substrates (Derr et al., 2015; Riley, 2003; Wehtje et al., 1993); however, minimal amounts are typically detected in most situations. Herbicides labeled for use in container production generally have comparatively low solubility (Senseman, 2007).

Little information is available on the impact of microirrigation or drip irrigation systems on weed control in comparison with overhead systems. It would be assumed that these systems would likely decrease weed growth because, at least in larger containers, it is common that only a portion of the substrate surface may be wetted with each irrigation cycle. Although this would possibly decrease the ability of certain weed seeds to germinate, it may inadvertently cause other problems relating to weed control. Issues associated with micro or drip irrigation systems typically include a lack of herbicide activation due to the absence of rainfall and chances of phytotoxicity due to insufficient overhead irrigation to wash herbicide residues off plant foliage (if overhead applications are made). The advantages and disadvantages of these systems have been realized in real-world scenarios; however, they have not been documented in scientific literature. Furthermore, few studies have examined the impact of novel irrigation practices on weed growth. For example, advanced irrigation management techniques which incorporate deficit volume applications (Beeson, 2006), use of near-zero leachate irrigation regimes (Sammons, 2008), and implementation of new technologies, such as soil moisture sensors (Chappell et al., 2013; van Iersel et al., 2013), have been shown to 
result in dramatic water savings. However, no investigations have focused on the advantages or disadvantages of these systems on weed management. Simply applying irrigation in the most efficient manner possible, both in terms of quantity and location, would likely result in reduced weed growth simply due to less available water for germinating seedlings. It is also possible that these methods could improve herbicide performance by reducing the rate of microbial or chemical degradation (i.e., hydrolysis). It is important to determine the influence of irrigation practices on herbicide performance and weed growth to select the most appropriate active ingredients. A better understanding of herbicide performance based on multiple wet-dry cycles in container substrates could also be important when considering seasonal differences among various regions that routinely experience more or less frequent rainfall during certain times of the year.

Substrates management. Although there are several different kinds of substrates commonly used in the nursery industry, most are comprised of pine bark or douglas fir bark, sand, peat, or some other additive. These substrates, or mixes of various components, will vary in particle size, bulk density, porosity, water holding capacity, and air space. Although various physical properties will define the water and air holding capacity of the substrate, they may also impact sorption of preemergence herbicides and its influence on weed germination and growth.

In most cases, research has confirmed that most preemergence herbicides labeled for use in nursery crops are highly adsorptive to organic horticultural substrates. Grey et al. (1996) evaluated the adsorption, mobility, and filtration of metolachlor when applied to substrates including peat, pine bark, combinations of peat and pine bark, and pine bark:sand media. In column leaching studies, data indicated that metolachlor was relatively immobile through all substrates and substrate combinations. Others evaluating leaching potential of metolachlor have reported similar findings indicating that metolachlor is tightly bound to organic substrates (Koncal et al., 1981; Mahnken et al., 1994). Oxyfluorfen, one of the most common preemergence herbicides used in container nurseries (Case et al., 2005), has been shown to be slightly more mobile in pine bark compared with peat, but was largely immobile in both substrates (Horowitz and Elmore, 1991). Other studies with preemergence herbicides, including isoxaben (Rouchaud et al., 1999), oxadiazon, and oryzalin (Wehtje et al., 1993), have shown to be strongly sorbed by organic nursery substrates, such as peat or pine bark. While it is common for these herbicides to be found in irrigation runoff, it is likely that this is largely due to herbicides being applied to areas outside the targeted containers and not due to leaching through substrates (Gilliam et al., 1992; Wilson et al., 1996).

Research by Wehtje et al. (2009) evaluated efficacy of prodiamine, flumioxazin, and isoxaben applications on crabgrass, eclipta, and spotted spurge, respectively, in standard pine bark and alternative wood-based substrates. Alternative substrates evaluated included clean chip residual and WholeTree, both wood-based forestry byproducts developed from different portions of pine trees (Boyer et al., 2008; Fain et al., 2008). Results showed that weed control was similar between the pine bark substrate and two alternatives when label rates of the herbicides were applied. In the nontreated controls, weed growth tended to be either less (crabgrass and spotted spurge) or similar (eclipta) between pine bark and the alternatives. Authors concluded that the herbicides evaluated would likely provide similar and/or superior results in alternative substrates compared with the pine bark industry standard when labeled rates of herbicides are used. In this study, all substrates were hammer-milled before analysis in order for all to have similar physical properties, preventing this variable from influencing results. However, it is unclear how different particle sizes among substrates may have affected results, in terms of either herbicide efficacy or weed germination and/or growth. In addition to these alternative wood-based substrates, multiple types of agricultural or industrial wastes have been evaluated for use in container culture, including mushroom compost, turkey or chicken litter, paper waste products, wood chips, dried distillers grains, and varies types of tree barks (Boydston et al., 2008a, 2008b; Chong, 2005). Other than research on various wood-based substrates, no additional studies have examined the influence of different substrates or substrate components on weed growth or management techniques.

Few studies have examined the impact of physical properties, specifically particle size, on herbicide movement and sorption through homogeneous substrates, such as pine bark. In their 2007 study, Simmons and Derr observed a greater depth of pendimethalin leaching in pine bark substrate when compared with that of field soils. Observations were likely due to the larger particle size, increased void space, and higher hydraulic conductivity rates of the pine bark substrate. While work conducted by Grey et al. (1996) and others has shown similar adsorptive properties from pine bark, peat, or various mixtures, it is not clear what impact different particle sizes would have on herbicide leaching if similar substrates were evaluated across different physical properties.

Substrate particle size may influence weed seed germination and/or growth rates. In field soils, Keddy and Constabel (1986) demonstrated that species with small seeds had higher germination rates and greater growth in small particle size soils as compared with soils possessing large particles. The relationship between soil particle size and weed germination success and growth, however, was not observed with larger weed seeds. This reported observation may have significant implications given that many common weed species found in container nursery production, such as bittercress, prostate spurge, or woodsorrel, tend to have small seeds. In studies using nursery substrates, Wada (2005) showed decreased growth and germination of pearlwort, northern willowherb, and common groundsel as substrate particle size increased. It is known that soils with larger particle sizes do not retain as much water as those with smaller particles, especially at the surface of the substrate, which is significant in terms of weed germination rates. If irrigation regimes were altered to account for differences in substrate properties, higher moisture levels may have been observed in substrates with smaller particle sizes and less air space. It is also possible that smaller weed seeds moved further down in the substrate profile and did not have adequate sunlight needed for germination. Although some studies have suggested that substrates with larger particle sizes could potentially reduce weed seed germination, nutrient and water holding capacity might be sacrificed or irrigation and fertilization practices may need to be altered. A study conducted by Chambers and MacMahon (1994) found that field soils with large particle sizes did not have the nutrient or water holding capacity of substrates with smaller particle sizes and therefore may not provide crops with the water and/or nutrient holding capacity necessary for optimal growth and survival.

The influence of age and handling of substrates directly affects the chemical and physical properties of substrates. The influence of these properties on weed management is poorly documented in scientific literature. A recent survey found substrates used in the nursery industry are typically aged from 6 weeks to over 1 year, which dramatically affects substrate chemical and physical properties (Jackson, 2014). The substrate aging processes, use of fresh or "green" substrates, harvesting methods, pine species, and other variables all influence the final product, as does whether the substrate was hammer-milled or screened before or after aging (Bilderback et al., 2005; Fields et al., 2014; Jackson, 2014). It is known that age and handling of pine bark supplies before use dramatically impact particle size, thus impacting air space and multiple other chemical and physical properties (Jackson et al., 2009).

Key knowledge gaps and opportunities. The container nursery industry as a whole has made tremendous advancements in the production of container-grown ornamentals from substrate management, irrigation, fertilization, and from a pest management perspective. The many benefits of various irrigation practices and new irrigation technologies have been well documented in terms of water savings and crop growth. Growers also now have the ability to choose from countless formulations, slow-release coatings, and nutrient sources for fertilization and can fertilize based on species-specific needs. It is becoming increasingly important to conserve water and use nutrients more 
efficiently. These two goals often go hand-inhand (Yeager et al., 2010). As discussed earlier, there are likely numerous benefits to efficient water and nutrient practices in terms of weed management. In cases where there is no benefit, or detrimental effects have been reported, such as increased weed growth after cyclic irrigation practices, established and proven production practices should not, and likely would not, be altered to decrease weed growth. Yet, weed management approaches could be modified based on production practices that are already in place to conserve water, use fertilizers more efficiently, and/or promote the growth of more marketable crops if knowledge is available in regard to these interactions.

To develop a truly systems-based approach to weed management, a thorough understanding of how weed management practices will be impacted by all aspects of the production process is needed. The nursery industry poses many challenges to developing this information as these practices are very site specific and dramatically vary from one region to the next. More often than not, production practices will also be very different for different crops grown at the same nursery. With current challenges, including labor cost/availability, fluctuating housing markets, increasing regulation, and shifts in the demographic of the primary customer base, the nursery industry continues to face threats to profitability. Weed control is one issue in which small improvements can yield dramatic economic savings. Developing baseline data on which herbicides, herbicide rotations, and various other nonchemical approaches are most effective under differing production environments has the potential to result in significant cost savings for the industry.

\section{Literature Cited}

Abbey, T.M., T.L. Mervosh, A.F. Senesac, and I.T. Bradley. 2001. Mulches for weed suppression in containers of herbaceous perennials. Perennial Plant Assn. Qrtly. J. Autumn:9-24.

Ahn, J.K. and I.M. Chung. 2000. Allopathic potential of rice hulls on germination and seedling growth of barnyardgrass. Agron. J. 92:11621167.

Alam, M.Z., C. Chong, J. Llewellyn, and G.P. Lumis. 2009. Evaluating fertilization and water practices to minimize $\mathrm{NO}_{3}-\mathrm{N}$ leachate from container-grown forsythia. HortScience 44:18831837.

Altieri, M.A., A. van Schoonhoven, and J. Doll. 2009. The ecological role of weeds in insect pest management systems: A review illustrated by Bean (Phaseolus vulgaris) cropping systems. Intl. J. Pest Mgt. 23:195-205.

Altland, J. 2014. Weed control in herbaceous perennial container production. Greenhouse Product News. 20 Aug. 2017. <http:/gpnmag.com/ wp-content/uploads/06_Research_GPN0914\% 20FINAL.pdf $>$.

Altland, J.E., G.B. Fain, and K. Von Arx. 2004. Fertilizer placement and herbicide rate affect weed control and crop growth in containers. J. Environ. Hort. 22:93-99.

Amoroso, G., P. Frangi, R. Piatti, and A. Fini. 2009. Mulching as alternative to chemical weed control in nursery containerized crops. Adv. Hort. Sci. 23:276-279.

Andersen, R.N. 1968Germination and establishment of weeds for experimental purposes. Urbana, IL: Weed Science Society of America. Asgarpour, R., R. Ghorbani, M. Khajeh-Hosseini, E. Mohammadvand, and B.S. Chauhan. 2015. Germination of spotted spurge (Chamaesyce maculata) seeds in response to different environmental factors. Weed Sci. 63:502-510.

Beeson, R.C. 2006. Relationship of plant growth and actual evapotranspiration to irrigation frequency based on management allowed deficits for container nursery stock. J. Amer. Soc. Hort. Sci. 131:140-148.

Berchielli-Robertson, D.L., C.H. Gilliam, and D.C. Fare. 1990. Competitive effects of weeds in the growth of container-grown plants. HortScience 25:77-79.

Bilderback, T., C. Boyer, M. Chappell, G. Fain, D. Fare, C. Gilliam, B. Jackson, J. Lea-Cox, A. LeBude, A. Niemiera, J. Owen, J. Ruter, K. Tilt, S. Warren, S. White, T. Whitwell, R. Wright, and T. Yeager. 2013. Best management practices for nursery crops. 3rd ed. Southern Nursery Association, Atlanta, GA. 15 Feb. 2017. <http://contents.sna.org/>.

Bilderback, T.E., S.L. Warren, J.S. Owen, and J.P. Albano. 2005. Healthy substrates need physicals too! HortTechnology 15:747-751.

Blackshaw, R.E., R.N. Brandt, H.H. Janzen, T. Entz, C.A. Grant, and D.A. Derksen. 2003. Differential response of weed species to added nitrogen. Weed Sci. 51:532-539.

Blackshaw, R.E., L.J. Molnar, and H.H. Jansen 2004. Nitrogen fertilizer timing and application method affect weed growth and competition with spring wheat. Weed Sci. 52:614-622.

Boland, G.J. and R. Hall. 1994. Index of plant hosts of Sclerotinia sclerotiorum. Can. J. Plant Pathol. 16:93-108.

Boydston, R.A., T. Anderson, and S.F. Vaughn. 2008a. Mustard (Sinapis alba) seed meal suppresses weeds in container grown ornamentals. HortScience 43:800-803.

Boydston, R.A., H.P. Collins, and S.F. Vaughn. 2008b. Response of weeds and ornamental plants to potting soil amended with dried distillers grains. HortScience 43:191-195.

Boyer, C.R., G.B. Fain, C.H. Gilliam, T.V. Gallagher, H.A. Torbert, and J.L. Sibley. 2008. Clean chip residual as a substrate for perennial nursery crop production. J. Environ. Hort. 26:239-246.

Brabham, C., L. Lei, Y. Gu, J. Stork, M. Barrett, and S. DeBolt. 2014. Indaziflam herbicidal action: A potent cellulose biosynthesis inhibitor. Plant Physiol. 166:1177-1185.

Broschat, T. and K.K. Moore. 2003. Influence of fertilizer placement on plant quality, root distribution, and weed growth in container-grown tropical ornamental plants. HortTechnology 13:305-308.

Brosnan, J.T., G.K. Breedon, P.E. McCullough, and G.M. Henry. 2012. Pre and post control of annual bluegrass (Poa апnиa) with indaziflam. Weed Technol. 26:48-53.

Brosnan, J.T., P.E. McCullough, and G.K. Breeden. 2011. Smooth crabgrass control with indazilam at various spring timings. Weed Technol. 25: 363-366.

Burger, D.W., J.S. Hartin, D.R. Hodel, T.A. Lukaszewski, S.A. Tjosvold, and S.A. Wagner. 1987. Water use in California's ornamental nurseries. Calif. Agr. 41:7-8.

Camp, C.R. 1998. Subsurface drip irrigation: A review. Trans. Amer. Soc. Agr. Eng. 41:13531367.
Case, L.T., H.M. Mathers, and A.F. Senesac. 2005. A review of weed control practices in container nurseries. HortTechnology 15:535-539.

Chambers, J.C. and J.A. MacMahon. 1994. A day in the life of a seed: Movement and fates of seeds and their implications for natural and managed systems. Annu. Rev. Ecol. Syst. 25:263-292.

Chappell, M., S.K. Dove, M.W. van Iersel, P.A. Thomas, and J. Ruter. 2013. Implementation of wireless sensor networks for irrigation control in three container nurseries. HortTechnology 23:747-753.

Chong, C. 2003. Experiences with weed discs and other non-chemical alternatives for container weed control. HortTechnology 13:23-27.

Chong, C. 2005. Experiences with wastes and composts in nursery substrates. HortTechnology 15:739-747.

Cobb, G.S. 1985. Comparison of fertilizer application methods for a single-component growth medium. Proc. Southern Nursery Assn. Res. Conf. 30:69-72.

Cochran, D.R., C.H. Gilliam, D.J. Eakes, G.R. Wehtje, P.R. Knight, and J. Olive. 2009. Mulch depth affects weed germination. J. Environ. Hortic. 27:85-90.

Conover, C.A. and R.T. Poole. 1985. Influence of fertilizer source, rate, and application method on growth of Brassaia actinophylla and Viburnum odoratissimum. Proc. Fl. State Hort. Soc. 98:82-85.

Darden, J. and J.C. Neal. 1999. Granular herbicide application uniformity and efficacy in container nurseries. Proc. Southern Nursery Assn Res. Conf. 44:427-430.

Derr, J., L. Robertson, and E. Watson. 2015. Leaching behavior of two pendimethalin formulations in a soilless growing medium. Weed Sci. 63:555-560.

DiTomasso, J.M. 1995. Approaches for improving crop competitiveness through the manipulation of fertilization strategies. Weed Sci. 43:491497.

Donnelly, P.K., J.A. Entry, and D.L. Crawford. 1993. Degradation of atrazine and 2,4dichlorophenoxyacetic acid by mycorrhizal fungi at three nitrogen concentrations in vitro. Appl. Environ. Microbiol. 59:2642-2647.

Dumroese, R.K., J.R. Pinto, D.F. Jacobs, A.S Davis, and B. Horiuchi. 2006. Subirrigation reduces water use, nitrogen loss, and moss growth in a container nursery. Native Plants J. 7:253-261.

Fain, G.B., C.H. Gilliam, J.L. Sibley, and C.R. Boyer. 2008. WholeTree substrates derived from three species of pine in production of annual vinca. HortTechnology 18:13-17.

Fain, G.B., K.L. Paridon, and P.M. Hudson. 2004. The effect of cyclic irrigation and herbicide on plant and weed growth in production of Magnolia grandiflora 'Alta'. Proc. Southern Nursery. Assn. Res. Conf. 49:37-39.

Fare, D.C., C.H. Gilliam, G.J. Keever, and J.W. Olive. 1994. Cyclic irrigation reduces container leachate nitrate-nitrogen concentration. HortScience 29:1514-1517.

Farina, M.P.W., P.E.L.L. Thomas, and P. Channon. 1985. Nitrogen, phosphorous and potassium effects on the incidence of Striga asiatica (L.) in maize. Weed Res. 25:443-447.

Fausey, J.C. 2003. Controlling liverwort and moss now and in the future. HortTechnology 13:35-38.

Fields, J.S., B.E. Jackson, and W.C. Fonteno. 2014. Pine bark physical properties influenced by bark source and age. 12 Jan. 2017. <https:// www.ncsu.edu/project/woodsubstrates/documents/ research/pine-bark-physical-properties.pdf $>$. 
Fretz, T.A. 1972. Weed competition in containergrown Japanese holly. HortScience 7:485-486.

Gilliam, C.H., D.C. Fare, and A. Beasley. 1992. Nontarget herbicide losses from application of granular Ronstar to container nurseries. J. Environ. Hort. 10:175-176.

Gilliam, C.H., W.J. Foster, J.L. Adrain, and R.L. Shumack. 1990. A survey of weed control costs and strategies in container production nurseries. Envrion. Hort. 8:133-135.

Goodwin, P.B., M. Murphy, P. Melville, and W. Yiasoumi. 2003. Efficiency of water and nutrient use in containerized plants irrigated by overhead, drip or capillary irrigation. Austral. J. Expt. Agr. 43:189-194.

Gough, C.M. and J.R. Seiler. 2004. Belowground carbon dynamics in loblolly pine (Pinus taeda) immediately following diammonium phosphate fertilization. Tree Physiol. 24:845-851.

Grattan, S.R., L.J. Schwankl, and W.T. Lanini. 1988. Weed control by subsurface irrigation. Calif. Agr. 3:22-24.

Grey, T.L., G.R. Wehtje, B.F. Hajek, C.H. Gilliam, G.J. Keever, and P. Pace. 1996. Adsorption, mobility, and filtration of metolachlor in container media. J. Amer. Soc. Hort. Sci. 121:478482.

Groves, R.L., J.F. Walgenback, J.W. Moyer, and G.G. Kennedy. 2002. The role of weed hosts and tobacco thrips, Frankliniella fusca, in the epidemiology of Tomatao spotted wilt virus. Plant Dis. 86:573-582.

Hayward, A.C. 1991. Biology and epidemiology of bacterial wilt caused by Pseudomonas solanacearum. Annu. Rev. Phytopathol. 29:65-87.

Hicklenton, P.R. 1990. Growth of capillaryirrigated Andorra juniper and Sarcoxie euonymus as affected by controlled release fertilizer type and placement. J. Environ. Hort. 8:92-95.

Horowitz, M. and C.L. Elmore. 1991. Leaching of oxyfluorfen in container media. Weed Technol. 5:175-180. Ingredient Indaziflam. 23 Nov. 2016. $<$ http://www.bayercropscience.com/bcsweb/>.

Jackson, B.E. 2014. Substrate discrepancies. Nursery Management. 15 Nov. 2016. <http://www. nurserymag.com/article/nm1014-pine-barkvariations-differences/ $>$.

Jackson, B.E., R.D. Wright, and J.R. Seiler. 2009. Changes in chemical and physical properties of pine tree substrate and pine bark during long-term nursery production. HortScience 44:791-799.

Jenkinson, P. and D.W. Parry. 1994. Isolation of Fusarium species from common broad-leaved weeds and their pathogenicity to winter wheat. Mycol. Res. 98:776-780.

Johnson, K.R. 2011. Sweet home Alabama? Immigration and civil rights in the "new" South. 2 Feb. 2012. <http://www.stanfordlawreview. org/online.sweet-home-alabama $>$

Judge, C.A. 2001. Predicting herbicide dissipation in container nursery crop production - a method for improving herbicide performance and reducing hand weeding. North Carolina State Univ., Raleigh, MS Thesis. 75 p.

Judge, C.A., J.C. Neal, and R.B. Leidy. 2003. Trifluralin (Preen) dissipation from the surface layer of a soilless plant growth substrate. J. Environ. Hort. 21:216-222.

Keddy, P.A. and P. Constabel. 1986. Germination of ten shoreline plants in relation to seed size, soil particle size and water level: An experimental study. J. Ecol. 74:133-141.

Kirkland, K.J. and H.J. Beckie. 1998. Contribution of nitrogen fertilizer placement to weed management in spring wheat (Triticum aestivum). WeedTech. 12:507-514.

Klock-Moore, K.A. and T.K. Broschat. 1999. Differences in bedding plant growth and nitriate loss with a controlled release fertilizer and two irrigation systems. HortTechnology 9:206209.

Koncal, J.J., S.F. Gorskey, and T.A. Fretz. 1981. Leaching of EPTC, alachlor, and metolachlor through a nursery medium as influenced by herbicide formulations. HortScience 16:757758 .

Landis, T.D. 1990. Containers and growing media, Vol. 2. p. 41-85. The container tree nursery manual. Agr. Handbook. 674. U.S. Dept. Agr. For. Serv., Washington, D.C.

Mahnken, G.E., W.A. Skroch, T.J. Sheets, and R.B. Leidy. 1994. Metolachlor and simazine leaching through horticultural substrates. J. Environ. Hort. 12:55-58.

Marble, S.C., C.H. Gilliam, G.R. Wehtje, and M. Samuel-Foo. 2013. Early postemergence control of yellow woodsorrel (Oxalis stricta) with residual herbicides. Weed Technol. 27:347351

Marble, S.C., S.A. Prior, G.B. Runion, H.A. Torbert, C.H. Gilliam, G.B. Fain, J.L. Sibley, and P.R. Knight. 2012. Effects of fertilizer placement on trace gas emissions from nursery container production. HortScience 47:1056-1062.

Martin, P.L. 2017Trump and U.S. immigration policy. Calif. Agr. 21 Jan. 2017. < http://calag.ucanr.edu/ Archive $/$ article $=$ ca. $2017 \mathrm{a} 0006 \&$ sharebar $=$ share $>$.

Mathers, H. 2003. Novel methods of weed control in containers. HortTechnology 13:28-31.

Mathers, H. and E. Ozkan. 2001. Herbicide treated mulches. Nursery Mgt. Prod. 17:61-64, 66.

Mumera, L.M. and F.E. Below. 1993. Role of nitrogen in resistance to Striga parasitism in maize. Crop Sci. 33:758-763.

Neal, J.C., J. Derr, C. Marble, and A. Senesac. 2017. Weed control, p. 120-197. 2017 southeastern U.S. pest control guide for nursery crops and landscape plantings. North Carolina State Extension, Raleigh, NC.

Norcini, J., A. Bolques, and R.H. Stamps. 2006. Container nursery weed control: Sanitation practices to prevent weed seed contamination. EDIS, Univ. of Florida. ENH1050.

Norcini, J.G. and R.H. Stamps. 1994. Container nursery weed control, Circular 678. Florida Coop. Ext. Serv., Inst. Food and Agr. Serv., Univ. of Florida, Gainesville, FL.

OHP, Inc. 2014. Marengo ${ }^{\circledR}$ herbicide product label. OHP, Inc. Mainland, PA. 8 p.

Rasmussen, K., J. Rasmussen, and J. Petersen. 1996. Effects of fertilizer placement on weeds in weed harrowed spring barley. Soil and Plant Sci. 46:192-196.

Richardson, B., C.H. Gilliam, G. Fain, and G. Wehtje. 2008. Nursery container weed control with pinebark mini-nuggets. J. Environ. Hort. 26:144-148.

Riley, M.B. 2003. Herbicide losses in runoff of containerized plant production nurseries. HortTechnology 13:16-22.

Rouchaud, J., O. Neus, M.C. Van Labeke, K. Cools, and R. Bulcke. 1999. Isoxaben and BAS $47914 \mathrm{H}$ retention/loss from peat substrate of nursery plants. Weed Sci. 47:602-607.

Sammons, J.D. 2008. Use of near-zero leachate irrigation systems for container production of woody ornamental plants. The Ohio State Univ., Columbus, OH, PhD Diss. 145 p.

Sands, R. and S. Nambiar. 1984. Water relations of Pinusradiata in competition with weeds. Can J. For. Res. 14(2):233-237.

Schmal, J.L., R.K. Dumroese, A.S. Davis, J.R. Pinto, and D.F. Jacobs. 2011. Subirrigation for production of native plants in nurseries concepts, current knowledge, and implementation. Native Plants J. 12:81-93.
Senseman, S.A. 2007. Herbicide handbook. 9th ed. Weed Science Society of America. Lawrence, KS. 458 p.

Shrestha, A., J.P. Mitchell, and W.T. Lanini. 2007. Subsurface drip irrigation as a weed management tool for conventional and conservation tillage tomato (Lycopersicon esculentum Mill.) production in semi-arid agroecosystems. 21 Feb. 2017. doi: 10.1300/J064v31n02_07.

Simmons, L.D. and J.F. Derr. 2007. Pendimethalin movement through pinebark compared to field soil. Weed Technol. 21:873-876.

Simpson, C.V., C.H. Gilliam, J.E. Altland, G.R. Wehtje, and J.L. Sibley. 2002. Postemergence oxalis control in container grown crops. Southern Nursery Assn. Res. Conf. 47:376-379.

Singh, U.R., D.P. Agarwal, and P.N. Pandey. 1989. Eclipta alba and Euphorbia hirta as new food plants and foci of infestations of Amsacta moorei Butl. (Lepidoptera: Arctiidae). Bull. Entomol. (New Delhi) 30:238-239.

Steed, S. 2015. Large scale recycling of used potting media with solarization. 22 Aug. 2017. $<$ https:// projects.sare.org/project-reports/os13-075/>.

Svenson, S.E. 1998. Suppression of liverworth growth in containers using irrigation, mulches, fertilizers, and herbicides. HortScience 33:485.

Taylor, J.E., D. Charlton, and A. Yunez-Naude. 2012. The end of farm labor abundance. Appl. Econ. Perspect. Policy 34:587-598.

Taylor-Lovell, S., G.K. Sims, and L.M. Wax. 2002. Effects of moisture, temperature, and biological activity on the degradation of isoxaflutole in soil. J. Agr. Food Chem. 50:5626-5633.

Teyker, R.H., H.D. Hoelzer, and R.A. Liebl. 1991. Maize and pigweed response to nitrogen supply and form. Plant Soil 135:287-292.

Thirukkumaran, C.M. and D. Parkinson. 2000. Microbial respiration, biomass, metabolic quotient and litter decomposition in a lodgepole pine forest amended with nitrogen and phosphorus fertilizers. Soil Biol. Biochem. 32: 59-66.

Thomas, S.H., J. Schroeder, and L.W. Murray. 2005. The role of weeds in nematode management. Weed Sci. 53:923-928.

Trivedi, P.C. and K.R. Barker. 1986. Management of nematodes by cultural practices. Nematropica 16:213-236.

United States Department of Labor. 2015. Bureau of labor statistics: Occupational employment and wages, May 2014. 9 Oct. 2016. <http:// www.bls.gov/oes/current/oes452099.htm>.

van Iersel, M.W., M. Chappell, and J.D. Lea-Cox. 2013. Sensors for improved efficiency of irrigation in greenhouse and nursery production. HortTechnology 23:735-746.

Vencill, W.K. (ed.). 2002. Herbicide handbook, 8th ed. Weed Science Society of America, Champaigne, IL.

Wada, S. 2005. Nursery container weeds response to modification of substrate $\mathrm{pH}$, substrate particle size and applied nitrogen form. Oregon State Univ., Corvallis, MS Thesis, 72-76 p.

Walker, K.L. and D.J. Williams. 1989. Annual grass interference in container-grown bush cinquefoil (Potentilla fruiticosa). Weed Sci. 37:73-75

Weber, J.B. 1990. Behavior of dinitroaniline herbicides in soils. Weed Technol. 4:394-406.

Wehtje, G.R., J.E. Altland, C.H. Gilliam, S.C. Marble, A.J. Van Hoogmoed, and G.B. Fain. 2009. Weed growth and efficacy of pre-applied herbicides in alternative rooting substrates used in container-grown nursery crops. Weed Technol. 23(3):455-459.

Wehtje, G.R., C.H. Gilliam, and B.F. Hajek. 1993. Adsorption, desorption, and leaching of 
oxadiazon in container media and soil. HortScience 28:126-128.

Wehtje, G.R., C.H. Gilliam, and J.A. Reeder. 1992. Germination and growth of leafflower (Phyllanthus urinaria) as affected by cultural conditions and herbicides. Weed Sci. 6:139-143.

Werle, R., L.D. Dandell, D.D. Buhler, R.G. Hartzler, and J.L. Lindquist. 2014. Predicting emergence of 23 annual weed species. Weed Sci. 62:267279.

Werth, J., M. Keenan, D. Thornby, K. Bell, and S. Walker. 2017. Emergence of four weed species in response to rainfall and temperature. Weed
Biol. Mgt. 24 Jan. 2017. <http://onlinelibrary. wiley.com/doi/10.1111/wbm.12113/abstract>.

Wilen, C.H., U.K. Schuch, and C.L. Elmore. 1999. Mulches and subirrigation control weeds in container production. J. Environ. Hort. 17:174-180.

Williams, A.P. 2009. The influence of soilless growing media on the movement and longevity of the herbicide dimethenamid-p. University of Georgia, Athens, GA, MS Thesis. 74 p.

Wilson, P.C., T. Whitwell, and M.B. Riley. 1996 Detection and dissipation of isoxaben and trifluralin in containerized plant nursery runoff water. Weed Sci. 44:683-688.
Yeager, T., J. Million, C. Larsen, and B. Stamps. 2010. Florida nursery best management practices: Past, present, and future. HortTechnology 20:82-88.

Yeager, T.H. and D.L. Ingram. 1987. Response of azalea and ligustrum to fertilizer placement and application rate. Proc. Southern Nursery Assn. Res. Conf. 32:88-90.

Yudin, L.S., J.J. Cho, and W.C. Mitchell. 1986. Host range of western flower thrips Frankliniella occidentalis (Tysanoptera:Thripidae), with special reference to Leucaena glauca. Environ. Entomol. 15:1292-1295. 